\title{
Selection of a Construction Contractor for Public Contracts in the Czech Republic according to Safe Tender Price
}

\author{
Frantisek Kuda $^{1, a}$, Eva Wernerova ${ }^{2, b}$, Stanislav Endel ${ }^{3, c}$ \\ $1,2,3$ VSB-TU Ostrava, FCE, Department of Urban Engineering, L.Podeste 1875, \\ Ostrava-Poruba, 70833, Czech Republic \\ a frantisek.kuda@vsb.cz , bevberankova@gmail.com, ${ }^{\mathrm{c}}$ stanislav.endel@vsb.cz
}

Keywords: whole-life costs, public contracts, safe price.

Abstract. The paper deals with life-cycle cost analysis in relation to public contracts. Public contracts in the Czech Republic are a very sensitive and frequently discussed area where the safe price, which would not include other investment in both implementation and usage phases of the facility, is discussed more and more often. Due to a lower acquisition price, the final quality of a building object suffers a loss. If the term safe price is incorporated in legislation, it is possible to influence the amount of operational and acquisition costs prior to implementation itself. The paper sets itself the aim of calling attention to the possibility of streamlining the selection of construction contractors in the process of public contract procurement and thus mitigating the impact of poorly executed construction work that will be reflected in the usage phase.

\section{Introduction}

The question of streamlining the acquisition costs when selecting a construction contractor is nowadays a topic frequently discussed in the legal environment of the Czech Republic. The Czech Republic, as one of the European Community members, incorporates the European legislation in its legal environment. It is understandable that the Ministry of Regional Development of the Czech Republic responded to the Directive of 26 February 2014 on public procurement and on cancellation of Directive 2004/18/EC by issuing Real Intent 49/14 in which, among other matters, it responds to the need for treatment of an extraordinary low tender price. Nowadays, construction engineers for public contracts are selected pursuant to the lowest tender price. The investor is always content with such an offer but from the perspective of the facility manager, this fact always becomes a threat in the form of apotential increase in operating costs. [1]

\section{Whole - Life Cost}

The expenses for the operation and usage of building objects are included in the whole life-costs, see Fig. 1, and details are dealt with in the standard ISO 15686-5 Buildings and Constructed Assets - Service life planning - Part 5: Life-cycle costing. When producing LCC analyses, it is the operating costs, constituting an important item, which deserve our attention. Detailed operating cost breakdown is given in Table 1. Nowadays, the classical approach to designing structures still prevails; this is the tendency to build an object within the planned time with the planned costs and to the required quality. However, the sustainability of the building is being accentuated more and more. This means that it is important to consider economic and socio-cultural criteria. If the investor is not the future user and the real estate is implemented for subsequent sale, he tries to minimize all the costs during the preparation and implementation of the building project, regardless of future operating costs, and he follows only the profits he gains from the sale of the real-estate, and the same holds true in public procurement. The enlightened investor, who is going to adhere to the principles of sustainable building, should put his mind to the analysis of total costs within the framework of the whole-life costs of the building (LCC - Life Cycle Cost) and to the evaluation of life-cycle in the light of impact on the environment (LCA - Life Cycle Assessment). 


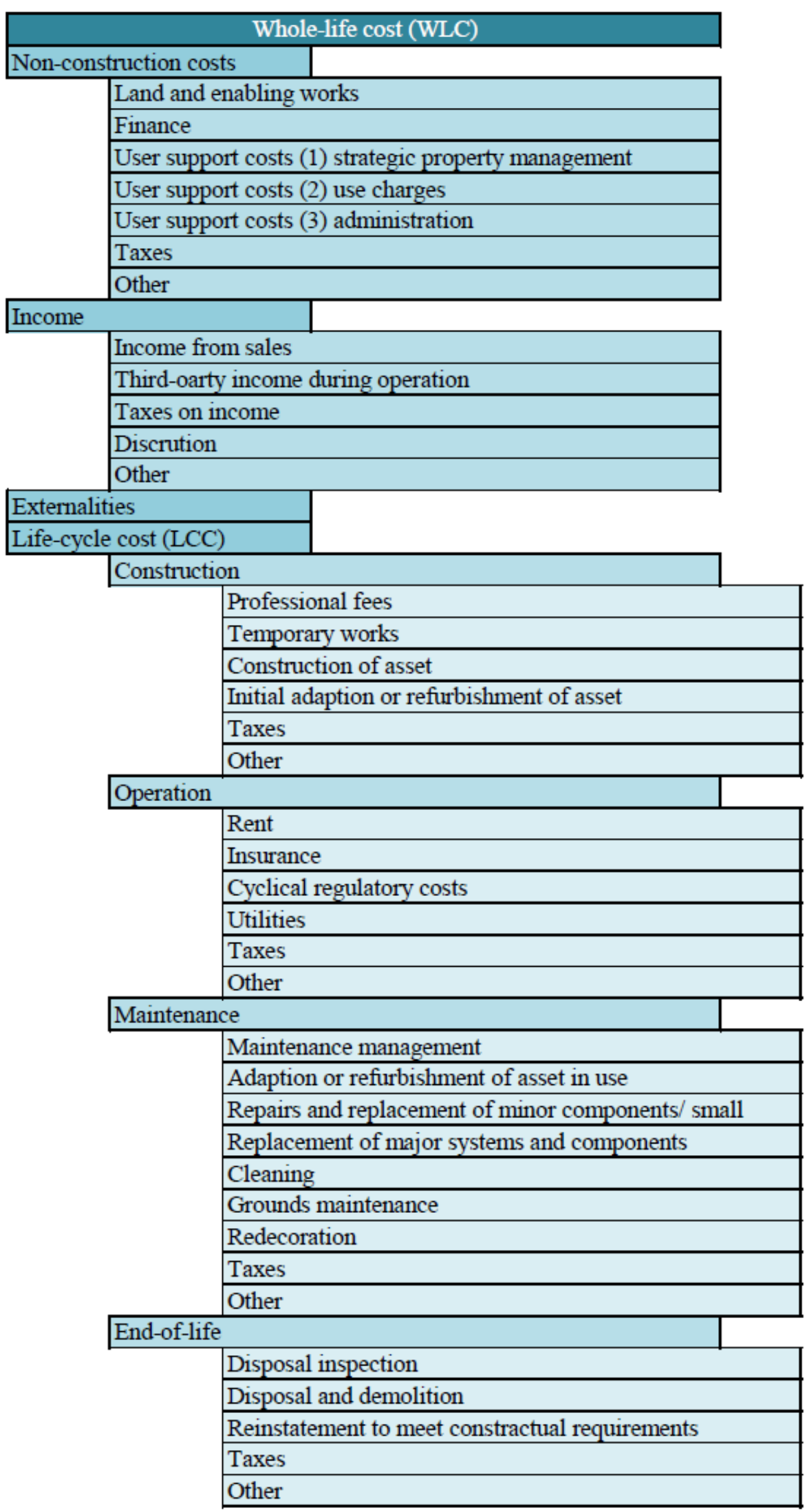

Fig. 1 Composition of whole life-cycle costs according to ISO 15686-5 [2] 
Table 1 Operating costs breakdown

\begin{tabular}{|c|c|}
\hline \multicolumn{2}{|r|}{ Operating costs breakdown } \\
\hline \multirow{9}{*}{$\begin{array}{l}\text { Operating costs } \\
\text { breakdown }\end{array}$} & Types of Energy use \\
\hline & Energy for heating \\
\hline & Energy for hot water heating \\
\hline & Energy for cooling \\
\hline & Energy for ventilation \\
\hline & Energy for humidity treatment \\
\hline & Energy for common area lighting \\
\hline & Consumption - other energies in housing units \\
\hline & Consumption - other energies in common area \\
\hline \multirow{3}{*}{$\begin{array}{l}\text { Operating costs } \\
\text { breakdown }\end{array}$} & Water and sewage \\
\hline & Water rate \\
\hline & Sewage charge \\
\hline $\begin{array}{l}\text { Operating costs } \\
\text { breakdown }\end{array}$ & Waste disposal \\
\hline $\begin{array}{l}\text { Operating costs } \\
\text { breakdown }\end{array}$ & Tidying up \\
\hline $\begin{array}{l}\text { Operating costs } \\
\text { breakdown }\end{array}$ & Greenery maintenance \\
\hline $\begin{array}{l}\text { Operating costs } \\
\text { breakdown }\end{array}$ & Object protection and surveillance \\
\hline \multirow{3}{*}{$\begin{array}{l}\text { Operating costs } \\
\text { breakdown }\end{array}$} & Building and property insurance \\
\hline & Real estate insurance \\
\hline & Other insurance \\
\hline \multirow{4}{*}{$\begin{array}{l}\text { Operating costs } \\
\text { brekdown }\end{array}$} & Administrative and service charges \\
\hline & Real estate tax \\
\hline & Inspection a service charges \\
\hline & Other charges \\
\hline
\end{tabular}

Safe tender price. By incorporation of this term in public contract legislation, there could be intervention in the selection of the construction contractor in such a manner that the implementation would be guaranteed by the price, corresponding with price standards not being extraordinarily low, and which would not constitute an actual increase in operating costs due to the practices of false economy and reducing the building acquisition costs. The safe tender price would be fixed by itemized listing of works and materials and would be submitted as one of the background materials for the assessment of tenders. This solution is referred to in the above mentioned Real Intent 49/14 of the Ministry of Regional Development of the Czech Republic. [3, 4] 


\section{Summary}

By incorporation of the safe tender price term in the public procurement legislation, the legislative power will indirectly put through the sustainable development concept during the implementation of work orders from public resources. Public procurement of construction works is currently a very sensitive or uncertain area where the work order is awarded to the supplier who offers the lowest tender price. This methodology is not the most advantageous selection strategy. It has come to light that the lowest tender price ultimately should mean high-quality implementation which does not induce any other investment costs in the implementation or usage phases. Therefore, the Ministry of Regional Development of the Czech Republic responded to the Directive and issued the Real Intent $49 / 14$ in which the introduction of this term is taken into account.

When analysing the life-cycle costs, it should be kept in mind that the operating costs are part of total costs and as such they constitute a substantially greater cost of usage and operation of the real estate than the costs of acquisition of the object and that the preparation and implementation of construction works plays an important role in future usage. Low acquisition costs fixed to an extraordinarily low tender price do constitute unnecessarily high operating costs and other investments induced in the usage phase.

\section{Acknowledgements}

The research work was supported by funds for the Conceptual Development of Science, Research and Innovation for 2015 allocated to VŠB-TUO by the Ministry of Education, Youth and Sports of the Czech Republic.

\section{References}

[1] KUDA, F. BERANKOVA, E. EU Approaches to Unification of Methodologies for Determination of Building Object Life Cycle Costing. In: Applied Mechanics and Materials. Volume 1044-1045, 2014, pp. 1863-1867.

[2] ISO 15686-5 Buildings and constructed assets - Service life planning - Part 5: Life-cycle costing. ICS: 91.040.01, Ed. 1, June 2008.

[3] Directive 2014/24/EU of the European Parliament and of the Council of 26 February 2014 on public procurement and repealing Directive 2004/18/EC Text with EEA relevance.

[4] Information on: <www.mmr.cz>. 